\title{
Biotech must consider sales incentives
}

IBM's OFA system blends the company's objective, the salesperson's forecast, and the actual sales achieved by the salesperson, while also calculating the salesperson's bonus.
Now that biotech companies are finally starting to enjoy sales they have to resolve some crucial commercial questions, including inventory turns, receivables management, and, yes, even compensation for salespeople. Even though incentives for salespeople are nagging puzzles for even the best companies, scientifically sound techniques have surfaced.

Most sales professionals revel in the art of exploiting any salesincentive program to maximize their personal gain. The "creativity" of salespeople is conspicuous when bonuses or commissions are tied to quotas. The first quota-based plans appeared during the volatile economic cycles before World War II. A salesperson, at that point typically male, was assigned a yearly quota. If he hit the target, he received a paid trip and a couple of days off, or was regarded as a "good guy for promotion." With the boom following the war, imperfections in these targeted quotas surfaced. Companies doled out larger perks or paid unexpected commissions for no more effort by the sales force than before. The disparity in the earnings' potential of salespeople increased with differences among sale territories.

The 1950s ushered in new compensations, known as sales-objective plans. These are still prevalent in industry today. Commissions are paid for quota completion only, or just for sales in excess of quota. Salespeople with good territories or greater sales prospects get higher objectives, or their territories are carved up among several salespeople. Sales-objective plans seem rational, because the quotas sum to meet the company's objective. Sales in excess of the quotas create extra profit for both the company and the sales force.

However, the strengths of this approach are its very shortcomings. Sales objectives are only as effective as the forecasts that support them. Nobody has precise techniques for forecasting the moderate sales figures of a "oneperson" territory. Also, sales forecasting has become the salesperson's enemy. Any request for an update or an estimate of new prospects automatically sets next year's quota. So projections by salespeople are understandably conservative, and the company usually distrusts these projections. A mutual-deception system results. An alternate incentive formula, pioneered by an IBM (Armonk, NY) salesperson in Brazil, Jacob Gonik, drives sales volume, pays for effort, and encourages collection of fresh field intelligence on the market's movements. IBM calls the system Objective, Forecast, Actual (OFA) because it blends the company's objective, the salesperson's forecast, and the actual sales achieved by the salesperson. It also calculates the percentage of a salesperson's bonus for which that person is eligible.

Here's how it works. Let's say Bill's employer has a sales objective of 1000 units of product for the period. Considering his knowledge of his customers and his skills, Bill agrees that 1000 units is a fair objective. If Bill actually sells 1000 units, he secures $120 \%$ of his bonus. He gets $100 \%$ for meeting the company's objective, as well as a $20 \%$ premium for his own good planning.

On the upside, if Bill sells double his forecast, or 2000 units, he takes home $180 \%$ of his bonus. Okay, so he is paid more for selling more. However, if Bill had forecasted 2000 units, instead of 1000 units, he would have received $240 \%$ of his bonus. Indeed, Bill loses a significant reward if he forecasts less than his real potential. On the downside, if Bill sells only 500 units, or $50 \%$ of his forecast of 1000 units, he gets just $30 \%$ of his bonus. But if he forecasts and sells 500 units instead of 1000 units, he takes in $60 \%$ of his bonus. Again, Bill is better off to forecast what his actual sales could be, even though this is lower than his employer's objective.

Overall, the salesperson has no choice but to forecast according to what he or she truly believes is achievable. The salesperson commits to achieving that goal, because falling short reduces income dramatically. Passing the comp- any's goal will increase income, but not by as much as if the salesperson would have forecasted higher.

The real beauty of OFA, though, is to make the salesperson think twice before delaying orders until the next period. "Sandbagging" orders by relegating them to the desk drawer is particularly common when current quotas are met. Suppose, for instance, that Bill enjoys an unexpected order for an extra 1000 units, after forecasting and achieving 1000 units. He receives $180 \%$ of his bonus. But if he delays the order and forecasts 2000 units for the next period's objective-the unexpected 1000 units plus the 1000 units he typically expects to sell-his bonus potentially becomes $240 \%$.

That's the rosiest of scenarios, though, one in which sandbagging actually pays off. So let's consider a more realistic scenario. For with OFA, every sales objective includes a part of any previously unfulfilled goal. If Bill delays his unexpected 1000 unit order and, consequently, falls short of his objective of 1000 units by, say, 500 units, his objective for the next period is automatically fixed at greater than 1000 units to, in this case, 1500 units. Bill's payoff for putting off the order declines to $160 \%$ of his bonus, which is lower than the $180 \%$ he would have gotten by delivering the order when it was placed. Bill sees the light and books the order in the period it was received. So, it seems, based on both the carrot and the stick, OFA is a fair and intelligible system for sales incentives.

III

George Kidd is president of management consultants Kidd \& Company (Shorewood, WI).

James Dvorak is an associate of Kidd \& Company.

For information on upcoming conferences, see this month's Classified section beginning on page 404. 